\title{
香港の日本語学習者減少の要因 \\ 一調查報告一 \\ Reasons for the decline number of Japanese language learners in Hong Kong \\ - Survey report -
}

\section{宇田川 洋子、李 夢娟、李 澤森、劉 礪志 香港日本語教育研究会}

\section{要旨}

本報告は、過去数年香港の日本語教育機関で問題となっている日本語学習者の減少の 要因を探ることを目的として実施した調查の報告である。

調査は「日本のイメージ」「将来の学習者数増減予想とその理由」「日本の自然災害や 原発事故、政治関係、経済問題などの学習意欲や日本へ行くことへの影響」「日本語学 習をやめたいと思ったことがある人の割合とその理由」「日本語学習の目的」に関して 行った。

この結果、現在日本語を学習寸る人については政治や経済問題は学習意欲にそれほど 影響していないが、仕事や学業の忙しさ、日本語上達の遅さ、会話練習の少なさなど の理由で日本語の勉強をやめようかと思ったことがあるということがわかった。また、 韓国語ブームや地震·原発への不安、政治や経済の問題などが新たな学習者の減少に影 響している可能性があることがわかった。

キーワード :

香港、日本語学習者、減少、学習意欲、学習目的 


\section{香港の日本語学習者減少の要因 \\ 一調查報告一}

\section{宇田川 洋子、李 夢娟、李 澤森、劉 磚志 香港日本語教育研究会}

\section{1.はじめに}

香港では、日本語能力試験（以下、JLPT）の応募者が、2009 年の 20,637 人を最高 に、減少の傾向にある(表 1)。また、香港の日本語学習者全体の減少も、多くの教育 機関から報告されている。そこで、香港日本語教育研究会（以下、研究会）の JLPT 実施委員会では、2012 年 11 月に香港の日本語学習者を対象に調查を行い、何が減少 の要因になっているのかを探らうと試みた（宇田川ほか、2013）。この調查から、日本 語学習者の中に、韓国語学習に興味を持つ人が増えていることや、日本での地震や原 発事故に対する不安を持つ人が多いことなどがわかってきたが、政治や経済の影響な ど、いろいろな面で明確にできなかった部分もあった。

また、2012 年の国際交流基金（以下、基金）の調査でも、香港の日本語学習者数は、 2009 年の 28,224 人から 22,555 人と、 $20 \%$ ちっと減少したとされている(基金、2013)。

このため、研究会では、前回の調查に続いて日本語学習者数の減少を探る調査を実 施することにした。今回は、JLPT の受験を辞めた理由よりも、日本語学習に注目し、 前回と同じ質問を 2 種、新しい質問を 2 種という構成にした。

\section{表 1 香港・マカオ地区における JLPT 応募者数の変化 研究会調へ（注 1）}

\begin{tabular}{|c|c|c|c|c|c|c|c|c|c|}
\hline 年 & 2005 & 2006 & 2007 & 2008 & 2009 & 2010 & 2011 & 2012 & 2013 \\
\hline 人 & 11551 & 13711 & 15546 & 17561 & 20637 & 14559 & 14589 & 12896 & 12546 \\
\hline
\end{tabular}

2009 年以降は年 2 回（7 月および 12 月実施分）の応募者合計

2010 年以前は 1-4 級、2010 年以降は N1-N5 応募者の合計

\section{2. 目的}

本調査は、次の $5 つ$ 点について聞くことによって、香港の日本語学習者の意識を 理解することを目的とした。

（1）日本に関するイメージの変化

（2）香港における将来の学習者数の予想とその理由

（3）日本の自然災害や原発事故、政治関係、経済問題などの学習意欲や日本へ行 くことへの影響

（4）日本語の勉強をやめたいと思ったことのある人の割合とその理由

(5) 日本語学習の目的

注 1 : 香港日本語教育研究会ウェブページ「日本語能力試験」の「統計資料」より $\underline{\text { http: //www. japanese-edu. org. hk/ }}$ (2013 年 8 月 1 日) 
（1）と（2）は前回の調查（宇田川ほか、2013）でも同じ質問をしているが、前 回の結果を見て、追加した項目もある。また、具体的な回答を得るために（ 3 ）を、 また、日本語学習についての（4）（5）を新たに加えた。

前回の調査では「友人や知人に JLPT を受験しようと思っていたがやめた人がいた か」という質問を設けたが、この質問で「はい」と答えた場合の理由が「申し込みの 期限を逃した」「自分の実力に自信がない」など、日本語学習者減少の要因とはあまり 関連性が高くないものが多かったと判断したので、今回は外した。

\section{3. 先行文献と 2012 年調査の関係}

1）「はじめに」に書いたように、香港や世界における日本語学習者数のデータは、 3 年ごとに実施されている基金の海外日本語教育機関調査の数字を参考にした。

2）香港における JLPT 応募者や受験者、その属性に関するデータは、試験の香港に おける実施機関である研究会が、毎年発行する論文集「日本學刊」で報告してい る（阮、2010、阮、2011、劉、2012、劉、2013）。

3 ）香港の日本語学習の目的に関する先行研究としては、基金（2011）、木山ほか （2011）などがあり、本調査の質問（日本のイメージ、学習目的）の回答選択肢 を作成する参考にした。

4) 香港の日本語学習者が日本語学習をやめたいと思ったときの理由に関しては、瀬 尾（2011）や瀬尾ほか（2012）の研究があり、本調査の選択肢を作成する参考に した。

\section{4. 調查方法}

1）対象者：香港の日本語学習者

2 ）依頼方法：2013 年 6 月に香港日本語教育研究会が JLPT 応募者（N3 と N5 の応募 者のみ）を対象として実施した調查活動のために集まった学習者に、印刷した調 查用紙を配布し口頭で依頼した。

3）調査方法: 協力者は調査用紙に直接記入する方法で回答し、研究会の担当者が回 収した。

4) 集計方法: 表計算機能のあるコンピュータープログラムにデータ入力し、集計し た。記述式の場合、中国語で書かれたものは日本語訳し、直接、表に入力した後 でカテゴリー分けなどを行った。 


\section{5. 集計結果}

\section{1 調查協力者}

受験者総数 778 人

表 2 : 日本語のレベル

\begin{tabular}{|c|c|}
\hline $\mathrm{N} 3$ & $\mathrm{~N} 5$ \\
\hline 392 人 $(50.4 \%)$ & 386 人 (49.6\%) \\
\hline
\end{tabular}

本調査の回答者が N3 と N5 の応募者に限られているのは、前回の調査同様、香港日 本語教育研究会が 2013 年 7 月の JLPTN3 と N5 の応募者が別件の調查のために集まった 機会を利用して本調査を行ったためである。

表 $3:$ 年齢層

\begin{tabular}{|c|c|c|c|c|c|c|}
\hline & 10 代 & 20 代 & 30 代 & 40 代 & 50 代 & 総数(人) \\
\hline N3 & $15.3 \%$ & $59.7 \%$ & $14.8 \%$ & $8.7 \%$ & $1.5 \%$ & 392 \\
\hline N5 & $19.2 \%$ & $47.2 \%$ & $21.5 \%$ & $9.6 \%$ & $2.6 \%$ & 386 \\
\hline 合計 & $17.2 \%$ & $53.5 \%$ & $18.1 \%$ & $9.1 \%$ & $2.1 \%$ & 778 \\
\hline
\end{tabular}

\section{2 回答の集計結果}

\section{2. 1 日本に関するイメージとその変化}

\section{2. 1. 1 日本と聞いて思い浮かべる言葉}

まず、「日本と聞いて思い浮かべる言葉を 3 つ書いてください。」に記述式で回答し てもらった。中国語による回答は日本語に翻訳し、カテゴリー別に整理した。例えば、

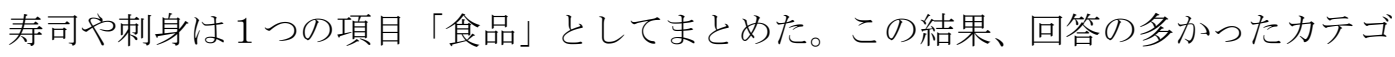
リー上位 10 項目をあげると、「食品」(52.6\%) が突出して多く、次に「アニメ」 $(24.8 \%) 、$

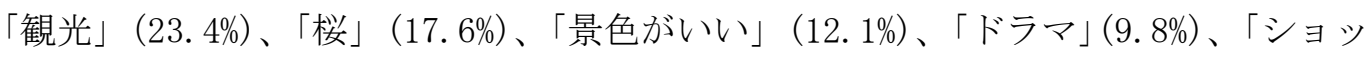

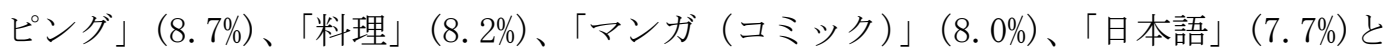
なった。これに続くのが「文化」「富士」「東京」「着物」「音楽」だった。このうち上 位 6 位まではN3、N5 とも順位が同じだった。

N3 と N5 で順位に開きが見られたものは「マンガ」（N3 は 7 位、N5 は 12 位）、「ショ ッピング」（N3 は 11 位、N5 は 7 位)、「東京」（N3 は 15 位、N 5 は 9 位）だった。また、 上位 20 項目のうち N3 にあって N5 にないものは「温泉」「アイドル」「神社やお寺」で、 N5 にしかないものは「綺麗」「ラーメン」「ゲーム」だった。 


\section{2. 1. 2 日本のイメージの変化}

次に、「あなたの日本に関するイメージは以前と比べて、最近変わりましたか。」と いう質問で、「全体」およびいろいろなカテゴリーについてのイメージの変化を調査し た。回答は「かなり向上した」、「少し向上した」、「変わらない」、「少し低下した」、「か なり低下した」の 5 つの選択肢から選んで答える。結果は以下のとおりだった。

\section{表 4 : 日本の全体的イメージ（全体および級別）}

\begin{tabular}{|c|c|c|c|c|c|c|c|}
\hline & $\begin{array}{c}\text { かなり } \\
\text { 向上 }\end{array}$ & 少し向上 & 変わらない & 少し低下 & かなり低下 & 総数 & 無回答 \\
\hline 合計 & $9.3 \%$ & $31.6 \%$ & $37.8 \%$ & $19.7 \%$ & $1.5 \%$ & 775 人 & 3 人 \\
\hline N3 & $7.2 \%$ & $34.1 \%$ & $40.0 \%$ & $16.7 \%$ & $2.1 \%$ & 390 人 & 2 人 \\
\hline N5 & $11.4 \%$ & $29.1 \%$ & $35.6 \%$ & $22.9 \%$ & $1.0 \%$ & 385 人 & 1 人 \\
\hline
\end{tabular}

2012 年の調査（宇田川ほか 2013）では、N2、N4、N5 の回答者の総計が、かなり向 上 $8 \%$ 、少し向上 $28 \%$ 、変わらない $41 \%$ 、少し低下 $21 \%$ 、かなり低下 $2 \%$ であった。 わずかではあるが、2013 年のほうがイメージが向上したほうの割合が増え、低下した ほうが減っている。

次に、年代ごとに分けてみてみると（表 5)、30 代から 50 代グループはイメージの 低下が著しい。反対に、10 代では「かなり向上」と「少し向上」の合計が $52 \%$ 半数 以上。N5 のほうが低下が多い数字になったのは、N5 のほうが 30 代、40 代の人が多い ためと考えられる。

表 5 : 日本の全体的イメージ（年代別）

\begin{tabular}{|c|c|c|c|c|c|c|c|}
\hline & $\begin{array}{c}\text { かなり } \\
\text { 向上 }\end{array}$ & 少し向上 & 変わらない & 少し低下 & かなり低下 & 総数 & 無回答 \\
\hline 10 代 & $14.9 \%$ & $36.6 \%$ & $29.9 \%$ & $17.9 \%$ & $0.0 \%$ & 134 人 & 1 人 \\
\hline 20 代 & $7.7 \%$ & $31.7 \%$ & $40.9 \%$ & $17.8 \%$ & $1.4 \%$ & 416 人 & 2 人 \\
\hline 30 代 & $10.6 \%$ & $27.0 \%$ & $36.2 \%$ & $25.5 \%$ & $0.7 \%$ & 141 人 & 0 人 \\
\hline 40 代 & $7.0 \%$ & $26.8 \%$ & $38.0 \%$ & $22.5 \%$ & $5.6 \%$ & 71 人 & 0 人 \\
\hline 50 代 & $0.0 \%$ & $43.8 \%$ & $31.3 \%$ & $18.8 \%$ & $6.3 \%$ & 16 人 & 0 人 \\
\hline
\end{tabular}

続いて、12 の日本に関するイメージについて、全体のイメージと同じ $5 つ$ 選択肢 から選んでもらった（表 6)。表の項目名は質問を短縮したものあるいは代表したもの を用い、本文には短縮形を質問の後に（）で示した。また、N3 と N5 を別々に集 計してみたところ、「全体」同様、級による大きな特徵はなく、合計の場合とほぼ同じ 傾向が見られた。 
5 つの選択肢のうち「向上」のどちらかを選んだ人が最も多かった項目は、「日本の 全体的イメージ (全体)」「観光地・旅行先としての日本（観光）」「日本料理や日本製 の食べもの（料理）」「日本の文化（マンガ、歌、アニメを含むテレビ番組など）（ポッ プ)」「ファッション」「日本の科学技術（技術）」の6つ。

イメージが低下したという選択が最も多かったのは「日本の政治（政治）」「日本の 経済（経済）」の 2 つで、いずれも50\%を超える回答者がイメージの低下を選んでい る。「日本の政治」、「日本の経済」、「日本の科学技術」の3つのカテゴリーは、前回の 調査の際、これらの項目が日本語学習者の減少に影響しているのではないかという仮 説が出てきたため、今回の調査で新たに加えた項目である。これによって、「日本の政 治」「日本の経済」に対するイメージ低下がより明確になった。「日本の科学技術」は イメージの低下は顕著ではなかったが、これは原発事故との関連性が明確でなかった ためと考えられる。

表 6 : 日本に関するイメージの変化（カテゴリー別）

\begin{tabular}{|l|c|c|c|c|c|c|}
\hline & $\begin{array}{c}\text { かなり } \\
\text { 向上 }\end{array}$ & $\begin{array}{c}\text { 少し } \\
\text { 向上 }\end{array}$ & $\begin{array}{c}\text { 変わら } \\
\text { ない }\end{array}$ & $\begin{array}{c}\text { 少し } \\
\text { 低下 }\end{array}$ & $\begin{array}{c}\text { かなり } \\
\text { 低下 }\end{array}$ & 無回答 \\
\hline 日本の全体的イメージ & $9.3 \%$ & $31.6 \%$ & $37.8 \%$ & $19.7 \%$ & $1.5 \%$ & 3 人 \\
\hline 観光地・旅行先として & $23.4 \%$ & $41.8 \%$ & $23.3 \%$ & $9.9 \%$ & $1.5 \%$ & 1 \\
\hline 留学先として & $11.5 \%$ & $26.5 \%$ & $47.2 \%$ & $12.7 \%$ & $2.1 \%$ & 1 \\
\hline 就職先として(日本での就職) & $7.2 \%$ & $23.4 \%$ & $45.0 \%$ & $20.1 \%$ & $4.3 \%$ & 3 \\
\hline 就職先としての香港の日系企業 & $7.9 \%$ & $29.0 \%$ & $48.1 \%$ & $13.8 \%$ & $1.2 \%$ & 3 \\
\hline $\begin{array}{l}\text { 取引先としての日本の企業や } \\
\text { 香港の日系企業 }\end{array}$ & $5.4 \%$ & $25.8 \%$ & $58.1 \%$ & $9.7 \%$ & $1.0 \%$ & 2 \\
\hline 日本料理や日本製の食べ物 & $23.5 \%$ & $44.0 \%$ & $25.7 \%$ & $6.0 \%$ & $0.8 \%$ & 0 \\
\hline 日本の文化 (漫画、歌、アニメを & $28.4 \%$ & $36.4 \%$ & $22.4 \%$ & $12.1 \%$ & $0.6 \%$ & 1 \\
\hline 含むテレビ番組など) & $13.5 \%$ & $31.0 \%$ & $47.2 \%$ & $7.50 \%$ & $0.8 \%$ & 1 \\
\hline 日本の文化（文学や歴史） & $16.8 \%$ & $35.0 \%$ & $37.9 \%$ & $9.5 \%$ & $0.8 \%$ & 3 \\
\hline 日本のファッション & $1.3 \%$ & $7.5 \%$ & $36.2 \%$ & $40.9 \%$ & $14.2 \%$ & 1 \\
\hline 日本の政治 & $2.3 \%$ & $11.6 \%$ & $34.2 \%$ & $41.1 \%$ & $10.8 \%$ & 1 \\
\hline 日本の経済 & $9.0 \%$ & $32.0 \%$ & $39.6 \%$ & $17.6 \%$ & $1.8 \%$ & 0 \\
\hline 日本の科学技術 & & & & & \\
\hline
\end{tabular}


また、2012 年 11 月の調查結果（宇田川ほか 2013）と同一の質問について結果が異な るかどうかを見たいと考え、両調查に共通する N5 応募者だけの数字 (2012 年 238 人、 2013 年 386 人）を、両調查に共通したカテゴリーに関してだけ比較した。この結果、

「観光地・旅行先としての日本」や「留学先としての日本」のイメージについて「向 上」したと答えた人の割合の増加が著しい。一方、日本料理や日本製の食べ物は、2013 年のほうが「向上」も多い一方、「低下」の割合も少し増えている。

\section{表 $7: 2012$ 年調査と 2013 年調査の比較 (N5 レベル)}

\begin{tabular}{|l|c|c|c|c|c|}
\cline { 2 - 6 } \multicolumn{1}{c|}{} & $\begin{array}{c}\text { かなり } \\
\text { N5 レベルの比較 }\end{array}$ & $\begin{array}{c}\text { 少し } \\
\text { 向上 }\end{array}$ & $\begin{array}{c}\text { 変わら } \\
\text { ない }\end{array}$ & $\begin{array}{c}\text { 少し } \\
\text { 低下 }\end{array}$ & $\begin{array}{c}\text { かなり } \\
\text { 低下 }\end{array}$ \\
\hline 2013 観光地・旅行先として & $21.8 \%$ & $44.0 \%$ & $23.1 \%$ & $9.8 \%$ & $1.3 \%$ \\
\hline 2012 観光地・旅行先として & $9.2 \%$ & $26.1 \%$ & $41.6 \%$ & $21.4 \%$ & $1.7 \%$ \\
\hline 2013 留学先として & $11.7 \%$ & $26.2 \%$ & $47.0 \%$ & $12.7 \%$ & $2.3 \%$ \\
\hline 2012 留学先として & $5.5 \%$ & $22.7 \%$ & $48.7 \%$ & $19.7 \%$ & $3.4 \%$ \\
\hline 2013 就職先として(日本での就職) & $7.0 \%$ & $21.7 \%$ & $47.0 \%$ & $20.4 \%$ & $3.9 \%$ \\
\hline 2012 就職先として(日本での就職) & $5.0 \%$ & $20.2 \%$ & $45.4 \%$ & $22.7 \%$ & $6.7 \%$ \\
\hline 2013 日本料理や日本製の食ベ物 & $24.6 \%$ & $42.2 \%$ & $25.6 \%$ & $6.7 \%$ & $0.8 \%$ \\
\hline 2012 日本料理や日本製の食心゙物 & $16.0 \%$ & $33.2 \%$ & $46.6 \%$ & $3.8 \%$ & $0.4 \%$ \\
\hline
\end{tabular}

\section{2. 2 日本の自然災害や原発事故、政治関係などの学習意欲や渡日への影響}

前回の調査で、2011 年の東日本大震災とそれに伴う原発事故、将来の地震に対する 不安、領土問題などを含む政治関係などが日本語学習者減少の要因になっている可能 性が感じられたため、今回の調查では、イメージ調查に項目として加えるだけでなく、 より具体的な質問を設けた。

質問は 8つで、A 強くそう思う（表では「強く」）、B 少しそう思う（少し）、C あま りそう思わない（あまり）、D全くそう思わない（全く）、Eわからないの選択肢の中か ら一つを選ぶ形式とした。結果をパーセンテージで示したものが表 8 である。

結果を見ると、地震や原発事故の不安のために自分の学習意欲が低下したかという 問いに「強くそう思う」「少しそう思う」とした人は合計 $10 \%$ 以下だったが、政治問 題のために学習意欲がしたかという質問に「そう思う」のどちらかを選んだ人は合計 で16\%近くだった。

一方、地震や原発事故のために日本行きを慎重に考えると答えた人は多く、特に長 期滞在については $50 \%$ を超えている。「慎重に考える」は「行かない」「日本内の場所 を考える」など意味に幅があるが、あまり選択肢を狭めるより答えやすいと考え、中 国語で類似の意味になるということだったので使用した。また、政治的関係が良くな いために日本旅行や留学を慎重に考えるとする人は $30 \%$ 前後となっている。 
また、年齢別では、前の 2 つの質問で肯定的な回答が多かった 10 代だが、前の質問 ほど目立った特長は見られなかった。

表 8 : 日本の自然災害や原発事故、政治関係などによる学習意欲や渡日への影響

\begin{tabular}{|c|c|c|c|c|c|c|c|}
\hline & 質問項目 & 強< & 少し & あまり & 全< & $\begin{array}{c}\text { わから } \\
\text { ない }\end{array}$ & 無回答 \\
\hline (1) & $\begin{array}{l}2011 \text { 年 } 3 \text { 月の東日本大震災の後、 } \\
\text { 日本語学習意欲が低下した。 }\end{array}$ & $1.2 \%$ & $6.1 \%$ & $31.9 \%$ & $57.6 \%$ & 3. $1 \%$ & 13 人 \\
\hline (2) & $\begin{array}{l}\text { 将来日本で大きな地震があるか } \\
\text { もしれないと聞いて、日本語学習 } \\
\text { 意欲が低下した。 }\end{array}$ & $1.0 \%$ & $5.6 \%$ & $27.1 \%$ & $62.9 \%$ & 3. $4 \%$ & 8 人 \\
\hline (3) & $\begin{array}{l}\text { 福島第 } 1 \text { 原発の事故について知 } \\
\text { っ、日本語学習意欲が低下し } \\
\text { た。 }\end{array}$ & $1.7 \%$ & $8.3 \%$ & $27.1 \%$ & $60.1 \%$ & $2.7 \%$ & 8 人 \\
\hline (4) & $\begin{array}{l}\text { 領土問題など中日の政治問題で、 } \\
\text { 日本語学習意欲が低下した。 }\end{array}$ & $2.6 \%$ & $13.3 \%$ & $29.0 \%$ & $52.3 \%$ & 2. $7 \%$ & 10 人 \\
\hline (5) & $\begin{array}{l}\text { 地震や原発事故など日本の安全 } \\
\text { 性に不安があるので、旅行で日本 } \\
\text { に行くことは慎重に考えたい。 }\end{array}$ & $12.4 \%$ & $38.4 \%$ & $25.7 \%$ & $22.6 \%$ & $0.9 \%$ & 9 人 \\
\hline (6) & $\begin{array}{l}\text { 地震や原発事故など日本の安全 } \\
\text { 性に不安があるので、留学など長 } \\
\text { 期に日本に行くことは慎重に考 } \\
\text { えたい。 }\end{array}$ & $17.8 \%$ & $36.8 \%$ & $23.0 \%$ & $18.8 \%$ & $3.6 \%$ & 8 人 \\
\hline (7) & $\begin{array}{l}\text { 領土問題など中国と日本の政治 } \\
\text { 的関係があまり良くないので、旅 } \\
\text { 行で日本に行くことは慎重に考 } \\
\text { えたい。 }\end{array}$ & $5.2 \%$ & $21.4 \%$ & $37.1 \%$ & $34.5 \%$ & $1.8 \%$ & 7 人 \\
\hline (8) & $\begin{array}{l}\text { 領土問題など中国と日本の政治 } \\
\text { 的関係があまり良くないので、留 } \\
\text { 学など長期に日本に行くことは } \\
\text { 慎重に考えたい。 }\end{array}$ & $7.5 \%$ & $24.4 \%$ & $32.0 \%$ & $31.8 \%$ & 4. $3 \%$ & 7 人 \\
\hline
\end{tabular}

\section{2.3 将来の日本語学習者数に関する予想とその理由}

将来の香港の日本語学習者の数について、増えると思うか、減ると思うかを聞いた ところ表 9 のような結果になった。レベル別に見ると、「増える」とした人は N5 のほ うがN3 より割り合いが多く、「減る」としたのはN3の割合のほうがやや多かった。参 考までに 2012 年の数字も示しておく（2012 年の報告では小数点以下を四捨五入して いたが、ここでは比較のために小数点以下 1 位まで表示した）。 
表 9 : 将来の学習数の予想 (全体および級別)

\begin{tabular}{|c|c|c|c|c|c|}
\hline & 増える & 減る & 変わらない & 合計 & 無回答 \\
\hline 2013 年 N3+N5 & $47.0 \%$ & $31.9 \%$ & $21.1 \%$ & 778 人 & 0 \\
\hline 2013 年 N3 & $45.7 \%$ & $34.4 \%$ & $19.9 \%$ & 392 人 & 0 \\
\hline 2013 年 N5 & $48.4 \%$ & $29.3 \%$ & $22.3 \%$ & 386 人 & 0 \\
\hline 2012 年 N2+N4+N5 & $45.7 \%$ & $32.5 \%$ & $21.8 \%$ & 634 人 & 0 \\
\hline
\end{tabular}

年代別では、表 10 にあるように、「増える」とした人の割合が最も多かったのが 10 代の $60 \%$ で、反対に最も少なかったのが 30 代の $31 \%$ と大きな開きが見られた。また、

「減る」の割合が多かったのが 50 代で $56 \%$ 、次いで 40 代の $42 \%$ 、最も少ないのが 10

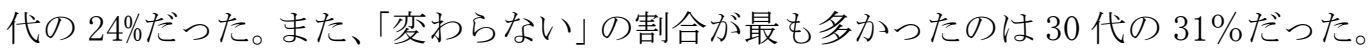

\section{表 10 : 将来の学習数の予想 (年代別)}

\begin{tabular}{|c|c|c|c|c|}
\hline & 増える & 減る & 変わらない & 合計 \\
\hline 10 代 & $59.7 \%$ & $24.6 \%$ & $15.7 \%$ & 134 人 \\
\hline 20 代 & $49.5 \%$ & $29.6 \%$ & $20.9 \%$ & 416 人 \\
\hline 30 代 & $31.2 \%$ & $37.6 \%$ & $30.5 \%$ & 141 人 \\
\hline 40 代 & $42.3 \%$ & $42.3 \%$ & $15.5 \%$ & 71 人 \\
\hline 50 代 & $31.3 \%$ & $56.3 \%$ & $12.5 \%$ & 16 人 \\
\hline
\end{tabular}

上記の答えに続いて、そう思う理由を複数選択可として選んでもらった。肯定的な 理由 12 件、否定的なもの 13 件の選択肢から選んでもらった。

集計の結果を肯定的な理由、否定的な理由に分けて、表にしたのが図 1 、図 2 であ る。「変わらない」とした人が両方の理由をどちらでも選べるため、割合ではなく、そ れぞれの項目を選んだ人数をそのまま記した。

肯定的な理由のうち選んだ人が多かったのは、多い順に「日本に旅行したい人が増 えるから」「日本の文化に興味を持つ人が増えるから」「日本語に興味を持つ人が増え るから」「日本が好きな人が増えるから」で、この順位はN N、N 5 共通であった。「日本 の経済状態が回復してきたから」が最も少なかったが、円安を理由として選んだ人は 5 番目に多かった。 


\section{図 1 ：日本語学習者が増える・変わらないと予想する肯定的理由}

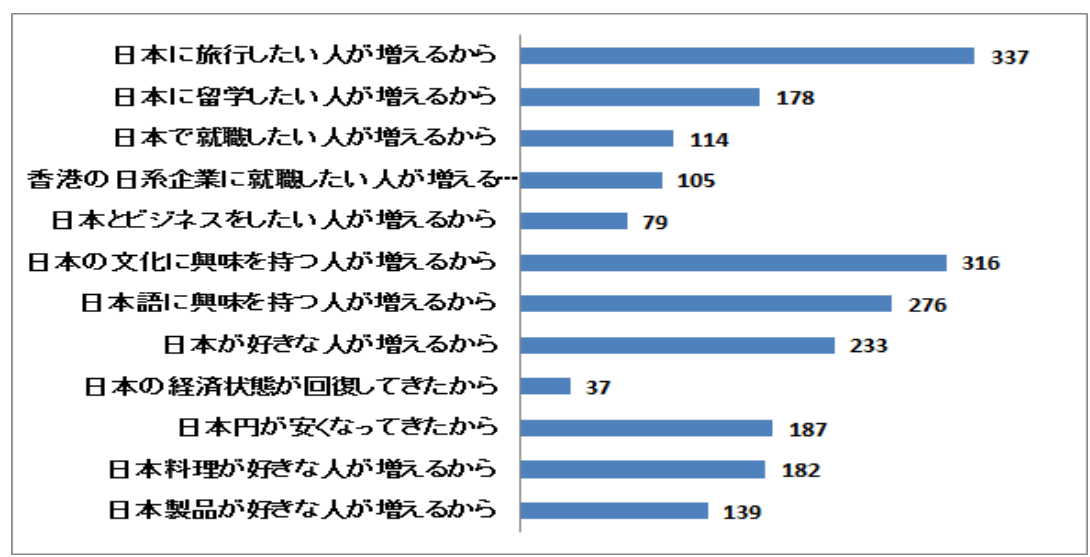

否定的な理由で最も多かったのが「ほかの外国語を勉強する人が増えるから」で、 この選択肢を選んだ人には何語が増えると予想されるかを書き込んでもらったところ、 韓国語 199、北京語 10、スペイン語 10、英語 1 、アラビア語 1 と、韓国語が圧倒的に 多かった。理由の 2 番目以下は、「原発など、日本の安全性に不安があるから」、「日本 の経済状態がよくないから」、「香港（中国）と日本の政治関係がよくないから」と続 いている。

ところで、5.2.2 で回答者本人の日本語学習意欲について聞いた際には、日本の安 全性への不安や政治・経済の問題は、自身の日本語学習にはあまり影響がないという 結果が出ていたが、将来の日本語学習者増減に関しては、要因の一つとして捉えられ ていることがわかる。

\section{図 2 : 日本語学習者が減る・変わらないと予想する否定的理由}

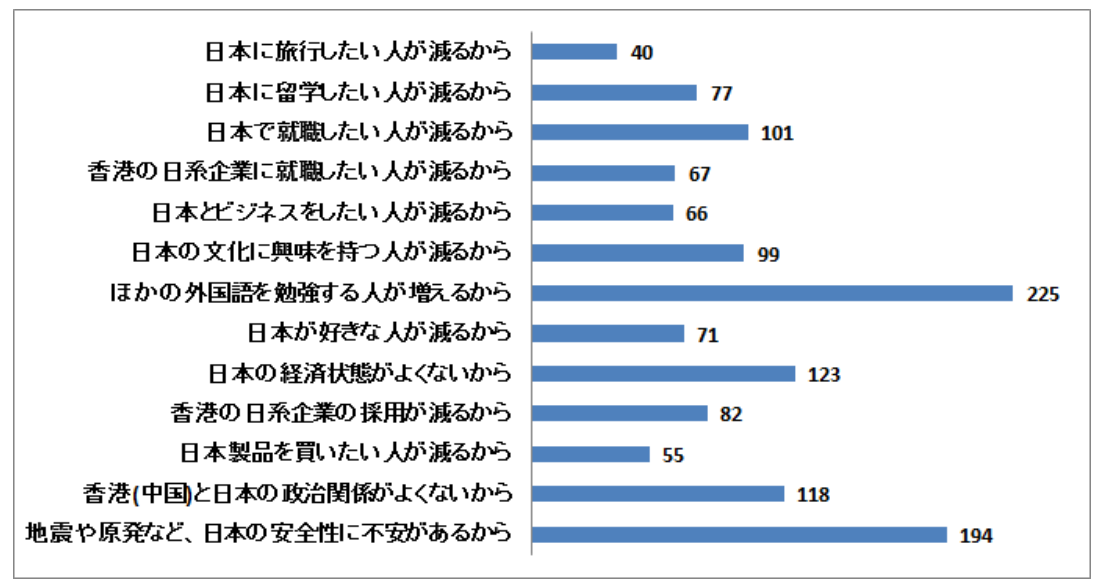


「その他」を選んだ人は 68 人で、記述の中には選択肢に該当する項目があるものも 含まれていたが、回答者の選択を尊重して「その他」に残した。否定的な理由では、 韓国文化の人気上昇 26 件、インターネットの翻訳機能などの普及、日系企業が日本語 より英語や中国語ができる人を求めるから、などがあった。また、肯定的なものでは、 就職に役立つ、日本文化の根強い人気などをあげる人がいた。

\section{2. 4 日本語学習をやめたいと思ったことがあるか}

この質問に対して、「はい」と答えた人は、無回答 10 人を除く 768 人中 201 人 $(26.2 \%)$ だった。N3 グループは「はい」と答えた人が $23.7 \%$ N5 は $28.3 \%$ N5 のほうが「日 本語学習をやめたい」と思ったことがある人の割合が多かった。年代別に見ると表 11 のように、「やめたいと思ったことがある」割合が最も多いのが 40 代で、また、10 代、 20 代のグループは約 $23 \%$ と割合が少ない。

\section{表 11 年代別 日本語をやめたいと思ったことがある割合}

\begin{tabular}{|l|c|c|c|c|c|}
\hline & 10 代 & 20 代 & 30 代 & 40 代 & 50 代 \\
\hline $\begin{array}{l}\text { 日本語学習をやめようと思 } \\
\text { つたことがある人の割合 }\end{array}$ & $23.1 \%$ & $23.1 \%$ & $30.5 \%$ & $36.6 \%$ & $31.3 \%$ \\
\hline 無回答 & 1 & 2 & 3 & 3 & 1 \\
\hline
\end{tabular}

図 3：日本語をやめたいと思った理由

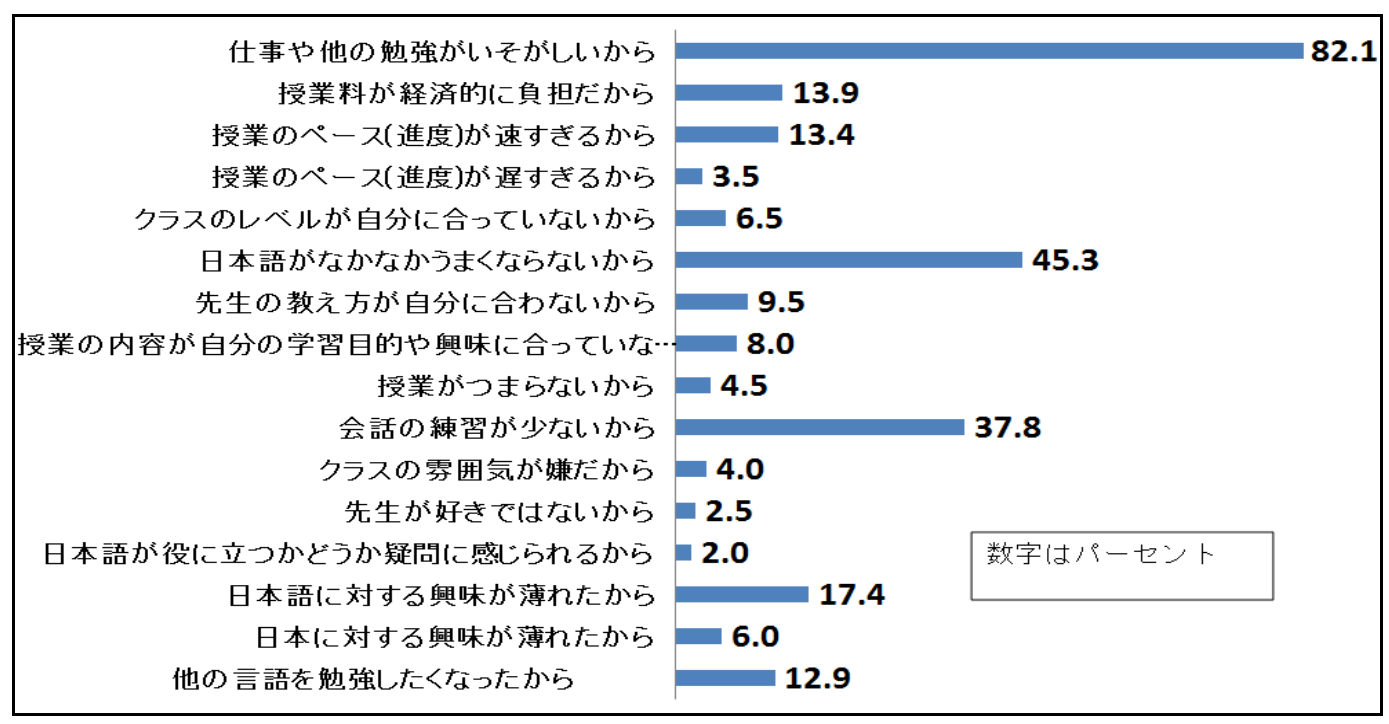


その理由について聞いてみると図 5 のようになった。突出して多かったのが「仕事 や他の勉強が忙しくて日本語の勉強に時間が割けないから」で、やめたいと思ったこ とがある 201 人中約 $82 \%$ の人がこの理由を選んでいる。これに続いて多いのが「日本 語がなかなかうまくならないから」、「会話の練習が少ないから」だった。

また、「他の言語を勉強したくなったから」という人に実際にどのような言語を勉強 したいと思ったのがを挙げてもらったところ、韓国語が 15 名、スペイン語が 5 名、英 語 1 名、フランス語 2 名、イタリア語 1 名だった。

「その他」の記述は 5 件で、このうち「レベルが合わない」というカテゴリーに含

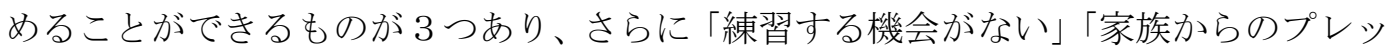
シャー」があったが、そのまま「その他」として扱った。

年代別に集計をしたのが表 12 である。これを見ると、10 代の傾向がかなりほかの 年代と異なっており、理由がさまざまであることがわかる。一方で、30 代から50 代 にかけては、上位 3 つ理由にかなり集中している。

\section{表 12 日本語をやめたいと思った理由}

\begin{tabular}{|l|c|c|c|c|c|}
\hline & 10 代 & 20 代 & 30 代 & 40 代 & 50 代 \\
\hline 仕事や他の勉強がいそがしいから & $77.4 \%$ & $88.5 \%$ & $81.4 \%$ & $69.2 \%$ & $80.0 \%$ \\
\hline 授業料が経済的に負担だから & $19.4 \%$ & $14.6 \%$ & $16.3 \%$ & $3.9 \%$ & $0.0 \%$ \\
\hline 授業のペース (進度)が速すぎるから & $9.7 \%$ & $12.5 \%$ & $18.6 \%$ & $11.5 \%$ & $20.0 \%$ \\
\hline 授業のペース (進度)が遅すぎるから & $6.5 \%$ & $4.2 \%$ & $2.3 \%$ & $0.0 \%$ & $0.0 \%$ \\
\hline クラスのレベルが自分に合っていないから & $12.9 \%$ & $5.2 \%$ & $7.0 \%$ & $3.9 \%$ & $0.0 \%$ \\
\hline 日本語がなかなからまくならないから & $35.5 \%$ & $40.6 \%$ & $46.5 \%$ & $61.5 \%$ & $100.0 \%$ \\
\hline 先生の教え方が自分に合わないから & $9.7 \%$ & $9.4 \%$ & $11.6 \%$ & $11.5 \%$ & $0.0 \%$ \\
\hline $\begin{array}{l}\text { 授業の内容が自分の学習目的や興味に合って } \\
\text { いないから }\end{array}$ & $12.9 \%$ & $8.3 \%$ & $4.7 \%$ & $7.7 \%$ & $0.0 \%$ \\
\hline 授業がつまらないから & $6.5 \%$ & $5.2 \%$ & $2.3 \%$ & $3.9 \%$ & $0.0 \%$ \\
\hline 会話の練習が少ないから & $25.8 \%$ & $29.2 \%$ & $46.5 \%$ & $65.4 \%$ & $60.0 \%$ \\
\hline クラスの雰囲気が嫌だから & $6.5 \%$ & $5.2 \%$ & $0.0 \%$ & $3.9 \%$ & $0.0 \%$ \\
\hline 先生が好きではないから & $6.5 \%$ & $2.1 \%$ & $2.3 \%$ & $0.0 \%$ & $0.0 \%$ \\
\hline $\begin{array}{l}\text { 日本語が役に立つかどうか疑問に感じられる } \\
\text { から }\end{array}$ & $22.6 \%$ & $25.0 \%$ & $7.0 \%$ & $19.2 \%$ & $20.0 \%$ \\
\hline 日本語に対する興味が薄れたから & $29.0 \%$ & $19.8 \%$ & $9.3 \%$ & $11.5 \%$ & $0.0 \%$ \\
\hline 日本に対する興味が薄れたから & $12.9 \%$ & $6.3 \%$ & $2.3 \%$ & $0.0 \%$ & $20.0 \%$ \\
\hline 他の言語を魅強したくなったから & $25.8 \%$ & $11.5 \%$ & $7.0 \%$ & $3.9 \%$ & $40.0 \%$ \\
\hline
\end{tabular}




\section{2. 5 日本語学習の目的}

木山ほか（2011）が 2010 年に香港の学習者を対象に実施した調査によれば、選択者 が多い順に「日本語でコミュニケーションができるようになりたい」「日本語自身に興 味がある」「日本が好きだから」「日本に旅行に行くため」が上位を占めている。

そこで、本調査の回答者グループに関しても同じ質問をしてみた。質問は木山ほか （2011）の選択肢のうち、選択の割合が 10\%に満たないものは省略し、必要があれば「そ の他」で記述できるようにした。表 6 は、回答者 778 人中それぞれのカテゴリーを選 んだ人数をパーセンテージで表したものである。

\section{表 13 日本語学習の目的}

\begin{tabular}{|l|r|}
\hline 質問項目 & 割合 \\
\hline 日本語でコミュニケーションができるようになりたい & $91.1 \%$ \\
\hline 日本語そのものに興味がある & $88.3 \%$ \\
\hline 日本へ旅行に行くため & $83.2 \%$ \\
\hline 日本が好きだから & $81.0 \%$ \\
\hline 日本の文化（アニメ、マンガ、ポップカルチャーなど） を知りたい & $74.2 \%$ \\
\hline 日本の食べ物について知りたい & $54.1 \%$ \\
\hline 日本の文化（文学や歴史）を知りたい & $50.8 \%$ \\
\hline 日本のファッションについて知りたい & $40.1 \%$ \\
\hline 国際理解・異文化理解の一環として & $35.9 \%$ \\
\hline 日本で働きたいため & $31.5 \%$ \\
\hline 日本との親善・交流のため & $28.4 \%$ \\
\hline 就職のため & $23.0 \%$ \\
\hline 留学のため & $20.7 \%$ \\
\hline 昇進のため & $16.3 \%$ \\
\hline 日本の科学技術について知りたい & $15.9 \%$ \\
\hline 日本の政治・社会経済について知りたい & $12.5 \%$ \\
\hline 大学や資格試験の受験準備のため & $12.5 \%$ \\
\hline 今の仕事のため & $8.7 \%$ \\
\hline 家族・親族等周囲の人に勧められたため & $6.0 \%$ \\
\hline
\end{tabular}

木山ほか（2011）と本調査を比較すると、上位 9 位までは同じ順位となったが、回 答者の日本語レベルが異なることなどから詳細な比較はここではしない。

また、「その他」には 17 の記述があり、「仕事のため」「日本へ留学したい」「テレビ 番組を理解したい」など選択肢の中に該当する回答があるものが 12 件あったが、回答 
者の選択を尊重し、そのまま「その他」として扱った。選択肢にない回答としては、

「日本人の友達がいるから」2 件や「日本人を知りたい」「日本人と友達になれる」各 1 件のように日本人との交流を示したもののほか、「大学で日本語を専攻したい」「日 本語教師になりたい」が各 1 件だった。

\section{6. 終わりに}

今回の調査からわかったことをまとめてみる。

香港で今、日本語を学習している人たちに関しては、中日の政治問題や日本経済の 低迷、地震や原発事故は、学習意欲にはそれほど大きな影響を与えていないが、留学 など、日本へ行くことについては影響を与えたと見られる。また、日本語学習をやめ ようかと考えるのは、忙しさが最も大きな要因になっているが、日本語上達が遅く感 じられること、会話の練習が少ないことなど、日本語学習に関連することが挙げられ ている。

また、地震や原発への不安や政治問題、韓国語学習の人気が、新たに日本語を学習 し始める人の数の減少に関係している可能性がある。

これらの結果を見ると、新たに学習を始める人と現在の学習者に対してでは異なる アプローチが必要であり、日本語学習の維持拡大に関しても、このような点に留意す ベきではないかと思われる。

\section{【謝辞】}

第 1 回調查、第 2 回調査共に、日本語能力試験協力委員会のメンバーである以下の方々 には貴重なご提案やご助言をいただきました。心よりお礼を申し上げます。

(名字の日本読みあいうえお順)

菊地 斉 元在香港日本国総領事館広報文化部長

趙 達栄 香港日本文化協会主席

陳 志誠 元香港城市大学教授

梁 安玉 香港日本語教育研究会会長

余 均灼 元香港中文大学教授 


\section{参考文献}

宇田川洋子・李夢娟・李澤森・劉獂志（2013）「香港の日本語能力試験受験者減少の要因を探る」

『日本學刊』第 16 号, 233-246

木山登志子・中野貴子・周宏陽・上田早苗・望月貴子・蘇凱達・青山玲二郎（2011）「2010 年香港

日本者背景調查報告」『日本學刊』第 14 号, 176-195

阮亦光（2010）「2009 年度香港・マカオ日本語能力試験実施報告」『日本學刊』第 13 号, 200-209

阮亦光（2011）「2010 年度香港・マカオ日本語能力試験実施報告」『日本學刊』第 14 号, 196-209

国際交流基金（2011）「日本語教育機関調査・2009 年＼cjkstart海外の日本語教育の現状」

国際交流基金（2013）「日本語教育機関調查・2012 年 海外の日本語教育の現状」くろしお出版 瀬尾匡輝 (2011)「香港の日本語生涯学習者の動機付けの変化一一修正版グラウンデッド・セオリー・

アプローチを用いた分析から探るー」『日本學刊』第 14 号, 16-39

瀬尾匡輝・陳徳奇・司徒棟威（2012）「なぜ日本語学習をやめてしまったのか一香港の社会人教育

機関の学習者における動機減退要因の一事例一」『日本學刊』第 15 号, 80-99

香港日本語教育研究会（2013）「日本語能力試験・統計資料」

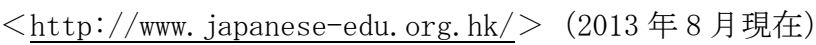

劉䃇志（2012）「2011 年度香港・マカオ日本語能力試験実施報告」『日本學刊』第 15 号, 136-148

劉䃇志（2013）「2012 年度香港・マカオ日本語能力試験実施報告」『日本學刊』第 16 号, 247-261 